\title{
BILJEŠKE O OPERNOM KAZALIŠNOM PODUZETNIŠTVU ISTOČNOGA JADRANA U AUSTROUGARSKOM RAZDOBLJU
}

\author{
Cristina SCUDERI \\ Karl Franzens Universität Graz \\ Institut für Musikwissenschaft \\ Graz, Mozartgasse 3 \\ cristina.scuderi@uni-graz.at
}

\author{
UDK 792(262.3-11)“1867/1918“ \\ Izvorni znanstveni članak \\ DOI https://doi.org/10.31726/via.25.6
}

\begin{abstract}
U radu se analiziraju razni aspekti operne produkcije u kazalištima istarske i dalmatinske obale kasnog austrougarskog razdoblja, počevši od nekih razmatranja o identitetu impresarija do analize njihovih glavnih zahtjeva i prijedloga nužnih za organizaciju operne sezone. Analiza također obuhvaća i pitanja okupljanja umjetničkoga kadra, prijevoza osoblja i dobara na teritorij te projekt umrežavanja kazališta.
\end{abstract}

Ključne riječi: Impresario, opera, Istra i Dalmacija, 19. i 20. stoljeće

Keywords: Impresario, opera, Istria and Dalmatia, 19th and 20th centuries

Parole chiave: Impresario, opera, Istria e Dalmazia, XIX e XX secolo

Praćenje podrijetla i rekonstruiranje aktivnosti kazališnih impresarija na jadranskoj obali na prijelazu između 19. i 20. stoljeća omogućuje nam da steknemo bolji uvid u mehanizme operne produkcije i organizacije na tom prostoru. Detaljno proučavanje rada glavnih aktera mehanizama produkcije predstava otkriva nam gustu mrežu odnosa koji su postojali između uprava kazališta, izdavača muzikalija, pjevača i glazbenika na području između Pule i Dubrovnika.

Održavanje bliske suradnje s kazališnim upravama u svrhu predlaganja operne sezone bio je i dalje u drugoj polovici 19. stoljeća zadatak opernoga impresarija, koji se tako nastojao istaknuti među mnogobrojnim konkurentima. Impresario je predlagao i umjetnički kadar di primo cartello, hvaleći se pritom brojnim poznanstvima u opernim krugovima i pokazujući time svoju solventnost (i kada bi ona bila očigledno nepouzdana). Iako različitog stupnja obrazovanosti, uglavnom bi u službu impresarija ulazili glazbenici, pjevači ili dirigenti koji su dolazili iz svijeta glazbe, ali i plesači, koreografi, pa čak i novinari ili odvjetnici koji su se usporedo sa svojim primarnim poslom, ili po svršetku karijere, počeli baviti poslovima impresarija. Tko su, dakle, bili impresariji koji su djelovali na na- 
vedenom teritoriju? Odakle su dolazili? Koje su strategije koristili kako bi osigurali jednu ili više kazališnih sezona na obali?

Neki su od impresarija bili podrijetlom iz Istre i Dalmacije te su djelovali lokalno. Međutim, većina impresarija nije bila domaćega podrijetla. Mnogi su dolazili iz Milana ili su odsjedali u Milanu u periodu komunikacije s kazališnim upravama na istočnojadranskoj obali. Ova nas činjenica ne iznenađuje, s obzirom da je taj grad bio središtem opere u Italiji. Arhivi iz Rijeke i Splita također otkrivaju brojne impresarije i agente koji su djelovali iz nekoga od referentnih gradova, poput Trsta, među kojima su najvažniji bili Giuseppe Ullmann, Giovanni Simonetti, Enrico Gallina, istodobno aktivni u više kazališta. Najčešća se pisana komunikacija odvijala između impresarija iz Rima, Venecije, Bolonje, Firence i Napulja.

Trenutno pripremamo registar impresarija i agenata aktivnih u kazalištima na istočnojadranskoj obali - odnosno sviju onih koji su stupili u kontakt s direkcijama istarskih i dalmatinskih kazališta. Jedina lista impresarija iz talijanske zone koju posjedujemo, ona koju je napravio John Rosselli osamdesetih godina, ${ }^{1}$ pruža vrlo ograničen uvid o ljudima koji su djelovali u Istri i Dalmaciji, bilo zbog kronoloških razloga (ondje navedeni impresariji isključivo su djelovali u razdoblju do kraja Prvoga svjetskog rata) ili različitih izvora iz kojih su prikupljeni materijali. Za većinu je od njih danas izrazito teško pronaći biografske podatke. Riječ je o osobama o kojima ne postoji historiografsko-biografska zabilješka. Odnosno, ako nešto i postoji, krije se u primarnim izvorima.

Bilo je također impresarija koji su pisali i djelovali iz naizgled dalekih, ali zahvaljujući parobrodima pristupačnih gradova, poput Barija i Ankone. Ako je, primjerice, u Dubrovniku ili Splitu nedostajalo dovoljno orkestralnih glazbenika, ponekad su bili poslani morskim putovima izravno iz Barija. ${ }^{2}$

Neki su se od hrvatskih impresarija također javljali iz kazališta u Osijeku i Zagrebu, međutim, ipak su i dalje bili manjinom koja je rijetko predlagala talijanske opere. ${ }^{3}$ Bilo je i onih koji bi u pratnji vlastitoga kazališnog ansambla dolazili iz Brna, poput direktora gradskoga kazališta Johanna Pisteka, nudeći opere Smetane i Čajkovskoga, ali i Verdija. U ovom slučaju, predlažući kazališnu sezonu u Splitu, zbog promjene općinske uprave iz talijanske $u$ hrvatsku, prema ugovoru impresario je bio obvezan osigurati izvođenje opera na hrvatskom, a ne na talijanskom jeziku. ${ }^{4}$ Početkom 19. stoljeća operne su se izvedbe hr-

1 Elenco provvisorio degli impresari e agenti teatrali italiani dal 1770 al 1890, sačuvan u knjižnici Odsjeka za umjetnost Sveučilišta u Bolonji.

2 Epidemije su bile nepovoljan čimbenik za kretanje glazbenika i pjevača: zbog epidemije kolere 1910. i 1911. godine u Dubrovniku se naročito strahovalo od dolaska umjetnika iz Barija. Još ranije, točnije, 1886. godine, u Zadru se prtljaga umjetnika obično dezinficirala, što bi rezultiralo troškovima koji su mogli obeshrabriti dolazak umjetnika iz inozemstva. Usp. pismo gradonačelnika Zadra kazališnoj direkciji, Zadar, 31. 8. 1886, HR-DAZD-252: Kazalište »Verdi« u Zadru 1863-1936, omotnica 25.

3 Usp. pisanu komunikaciju u: HR-DAŠI-103, Kazalište i kino »Mazzoleni« - Šibenik (1863-1945), omotnica 1, i ugovor između kazališta Mazzoleni i Leona Dragutinovića, upravnika Hrvatskoga narodnog kazališta u Osijeku, HR-DAŠI, omotnice 4 i 10.

4 U Splitu je 1882. godine administracija talijanske općine predala upravu hrvatskoj općini. Novi gradonačelnik Gajo Filomen Bulat bio je i direktor kazališta, baš kao i njegov prethodnik, talijanski 
vatskih kazališnih družina održavale čak i u Šibeniku iako su se u tom kazalištu nastavile izvoditi predstave i na talijanskom jeziku. Suprotno ovome, prema uvjetima natječaja, u Rijeci je korištenje talijanskoga jezika bilo obvezno. ${ }^{5}$ Izvodilo se program na talijanskom jeziku i u Puli - s prekidom u operetnim izvedbama na talijanskom jeziku između 1914. i 1918. godine ${ }^{6}$ - kao i u Zadru, iako to nije bilo obvezno ni po natječaju ni po ugovorima sklopljenim između kazališne direkcije i impresarija.

Sudionici kazališne sezone nisu se isključivo bavili glazbenim, nego i kazališnim predstavama, a pri kraju stoljeća i zabavnim predstavama - operetama i vodviljima. Dakle, potencijalne agencije koje su osnovali impresariji, bile su zapravo »višestruko specijalizirane«. Prema ondašnjem običaju, neki impresariji su posjedovali umjetničke časopise, koji su ujedno bili glavno upravljačko tijelo kazališne agencije te su se obraćali jadranskim kazališnim upravama zahtijevajući potpisivanje članarine ili njezino obnavljanje. Navest ćemo samo neke od mnogih tada aktivnih kazališnih agencija, poput kazališne agencije Curiel s časopisom La Frusta, agencije Francesca Lampertija s La Rivista teatrale ili Giovannija Simonettija s L'Arte.

Pišući u Istru i Dalmaciju, agenti i impresariji nastojali su osigurati višestruku korist. Naime, zbog dužine puta pokušavali su ugovoriti nastupe duž cijele obale. Onaj tko je već osigurao nastup u Puli, pokušavao je stići i do Zadra. Tko je stigao u Zadar, pokušavao je doseći barem Split. Prema dosadašnjim izvornim podatcima, obično se kretalo sa sjevera prema jugu, rjeđe obrnuto. Putovanja su impresarije u prosjeku koštala više od aktivnosti talijanskih družina na Apeninskome poluotoku. Uzimajući u obzir i nemogućnost podizanja cijene kazališnih ulaznica, takva su putovanja bila dodatan rizik. Dakle, mogućnost gubitka nije bila proporcionalna prednostima, odnosno financijskoj isplativosti. Družine su, naime, zahtijevale jamstvo i novac za nemali broj nastupa. Krajem stoljeća, ako ne bi bili plaćeni u lirama, veći su ansambli odbijali nastupe po Istri i Dalmaciji, dok su skromnije družine, poput izvođača vodvilja, pristajale na isplatu polovice ili dvije trećine ugovorenoga iznosa u lirama i ostatka u krunama po legalnom tečaju. Kako bi se angažirale družine, bilo je, dakle, potrebno uplatiti predujam u lirama, što je pojedinim kazališnim direkcijama bilo moguće jedino mijenjajući krune u talijanske lire.?

gradonačelnik Antonio Bajamonti. Usp. ugovor između kazališne uprave Splita i Johanna Pisteka, slovo »m« članka 1, Split, siječanj 1896., HR-MGS: Kazalište, 1/I-XII.

5 Usp. naprimjer, članak 1. u: Capitolato d'appalto per l'esercizio del Teatro Comunale nel triennio 1 gennaio 1909 - 31 dicembre 1911, i u: Capitolato d'appalto per l'esercizio del Teatro Comunale nel triennio 1 gennaio 1912 - 31 dicembre 1914, HR-DARI, Općinsko kazalište »G. Verdi«, DS 60.

6 ॥Već smo četiri godine bez predstava na talijanskom jeziku, već četiri godine životarimo na njemačkom...« (»Da quattr'anni siamo digiuni di spettacoli in lingua italiana, da quattr'anni vegetiamo nel tedesco...«) pisalo se u pulskom Biltenu; »Umjetnost je, kažu, internacionalna. Za nas, nije. [...] Družina njemačke operete zadržat će se u Puli sve do svibnja sljedeće godine. Nijemci će likovati i zabaviti se; Talijani će morati ostati kući.« (»L'arte, dicono, è internazionale. Per noi, no. [...] La Compagnia d'operette tedesche si fermerà a Pola sino a maggio del prossimo anno. I tedeschi goderanno, si divertiranno; gli italiani dovranno rimanere a casa.«), u: »Le operette tedesche al Ciscutti. Il teatro rinnovato«, Il Gazzetino di Pola, 8. 10. 1918.

7 Usp. pismo kazališne direkcije Šibenika predsjedničkoj upravi, Šibenik, 5. 9. 1919, HR-DAŠI-103, omotnica 4. Za pitanja o valutama ovoga perioda, a u svezi s aktivnostima kazališno-opernoga djelovanja 
Mnogi su se značajni troškovi koje su snosili impresariji ili kazališne direkcije mogli umanjiti međusobnim neposrednim kontaktom, odnosno dijalogom za kojim se osjećala jaka potreba još od 1870., a što se potvrđuje u dolje navedenim riječima direktora kazališta u Šibeniku, Paola Mazzolenija, upućenim neidentificiranom kolegi:

[...] kretat ćemo se uvijek iz lošeg u gore, nemajući ujedinjena tijela kazališnih uprava, nikada nećemo ništa dobro postići i nastavljajući djelovati u posljednjem trenutku morat ćemo dobro platiti nezasitno tržište, sve više degradirajući jadnu Dalmaciju. »Zajedništvo čini snagu«, a mi nismo ujedinjeni. Dakle, gore po nas. ${ }^{8}$

Pietro Ciscutti, osnivač Politeame u Puli (kasnije nazvanom po njegovu imenu), 1884. pokušao je sklopiti sporazum o pisanju predstava između kazališta u Puli, Rijeci i Zadru. »Nama upućene prijedloge«, pisao je Ciscutti direkciji u Zadru na svom stilistički nesavršenom, ali uvjerljivom talijanskom, »mi bismo također uputili njima, a oni bi u daljnjem pregovaranju mogli reći, da bi se nakon Zadra mogla uključiti i Pula kako bi se umanjili visoki putni i transportni troškovi. $\aleph^{9}$ Dakle, novih scenskih izvedbi ne bi bilo, a probe bi se odvijale brže. Kazališna je direkcija u Zadru ovaj prijedlog većinski prihvatila. Prvi je put ovo primijenjeno na operetnom ansamblu Meridionale koji je u listopadu 1884. krenuo iz Pule i stigao u Zadar u studenom, povodom ponovnoga otvaranja kazališta (kazalište je bilo privremeno zatvoreno ministarskom odlukom: u tijeku je bila obnova kazališta iz sigurnosnih razloga i protupožarne zaštite). ${ }^{10}$ Naposljetku su i Dubrovnik i Šibenik prihvatili prijedlog uspostavljanja bolje umreženosti. Ciscutti je više puta naglasio poteškoće s kojima su se mnogi impresariji suočavali prilikom dolaska u Pulu, a koje su se mogle ublažiti da su družine imale priliku tako veliki broj nastupa održati u više različitih kazališta. Moglo se znatno uštedjeti i na putnim i prijevoznim troškovima. No, uvjeti su za uspostavljanje takvoga ujedinjenog sustava, nažalost, izostali te je i skora Ciscuttijeva smrt 1890. godine onemogućila nastavak toga projekta. Impresariji su bili itekako svjesni rizika i izrazito nepovoljne situacije; unatoč tome nastavili su se truditi iznova se preporučujući kazališnim direkcijama.

usp. Michael WALTER, Oper. Geschichte einer Institution, Springer-Verlag, Stuttgart, 2016., poglavlje »Geld und Münzen«, str. 13-36.

$8 \quad »[\ldots .$.$] e sempre andremo di male in peggio, mentre mancando l'unione fra i vari corpi Presidenziali dei$ Teatri, mai e poi mai avremo alcunchè di buono e sempre riducendoci agli ultimi momenti dovremo pagare per buona, mercanzia avariata, e screditare sempre più la povera Dalmazia. "L'unione forma la forza" e noi siamo disuniti. Dunque peggio per noi.« Pismo [Ant. Jeoli?] Paolu Mazzoleniju, Split, 6. 10. 1870, HR-DAŠI-103, omotnica 1.

9 »Le proposte che verrebbero fatte a noi, noi le faressimo anche a loro, così a viceversa loro nel carteggio potrebbero dire, dopo Zara, potreste combinare Pola che allora le immense spese di viaggio e trasporti sarebbero diminuite.« Pismo Pietra Ciscuttija kazališnoj direkciji u Zadru, Pula, 3. 5. 1884, HR-DAZD-252, omotnica 5.

10 Pismo kazališne direkcije u Zadru upućeno Francescu Lucernu, Zadar, 28. 7. 1884, HR-DAZD-252, omotnica 5. 
Ukoliko je istinita tvrdnja Johna Rossellija da je »projekt postavljanja opere krajem 19. stoljeća više pitanje rizika i opasnosti negoli umjetnosti $\ll,{ }^{11}$ utoliko je zanimljivo da su se unatoč tomu mnogi impresariji nastavili truditi u organiziranju operne sezone. Kako bi se preporučio, impresario je pisao kazališnoj direkciji strukturirajući svoj zahtjev na osobito pažljiv i privlačan način, pogotovo u slučaju prvoga kontakta s nekom novom direkcijom. Analizom pisama iz istarskih i dalmatinskih arhiva moguće je utvrditi pojedine sličnosti kojima se oni ističu. Riječ je o učestalim zahtjevima upućenim direkcijama. Budući da je impresario prije svega morao zadovoljiti publiku, dvojbe oko izvedbe »opere serie $\ll^{12}$ ili pak nečega drugog, rješavale su se razmatrajući koja bi vrsta predstave bila posjećenija. Pojedini bi impresariji već u prvim prepiskama ukazivali na predložene opere, ostavljajući pritom mogućnost »u slučaju da vam se ne dopadnu, Vaša Visost neka kaže koje bi bile prihvaćenije mijenjajući repertoar «. ${ }^{13}$ Dakle, mogao se repertoar i modificirati. Neki bi tražili i uvid u uvjete natječaja kada ga nisu mogli pronaći objavljenoga u novinama ili pri agencijama.

Informacije o najprikladnijim vremenskim terminima za održavanje predstava, kao i o trajanju sezone bile su neke od najtraženijih. Raspitivalo se i o količini ukupno dopuštenih izvedbi, odnosno o broju predstava koje su se tjedno mogle ostvariti. S ekonomskoga gledišta, osim poznavanja iznosa jamčevine koja je bila zahtijevana u ime jamstva ugovora između kazališne direkcije i impresarija (ugovor bez jamčevine bio je nevažeći) i iznosa državnoga i industrijskog poreza, bilo je neophodno znati koliki bi bio iznos dobivenih sredstava. U zaključnom ugovoru s impresarijem, obećana su sredstva i naknadno mogla biti odobravana, uključujući i ustupanje određenoga broja pozornica. Jesu li pozornice privatno vlasništvo i mogu li se iznajmiti, bila je još jedna od potrebnih informacija. Bilo je potrebno informirati se i o iznosu večernjih kazališnih troškova, s ili bez orkestra, kao i o zaradi u slučaju popunjenoga kazališta, s mogućnošću ostvarivanja kvote bordereauxa prethodnih godina; potom o tome koliko su koštali članovi lokalnoga orkestra (novčani su se iznosi namijenjeni operi seriji i opereti razlikovali) i o načinu isplate osoblja.

Naravno, bilo je neophodno znati koliko je članova brojao lokalni orkestar te kojim je instrumentima raspolagao kako bi se u slučaju potrebe odlučilo o eventualnom sazivanju vanjskih instrumentalista. Za operu seriju bilo je važno znati broj članova zbora (postojala je mogućnost da za operetu zbor stigne već formiran), postojanje ili nepostojanje dirigenta (s odgovarajućom opremom), zborovođe, šaptača, itd., kao i dimenzije kazališta (visina, dubina, širina zgrade, prostor koji dijeli podij i publiku, podij itd.) i veličinu same pozornice.

Prema navedenim informacijama, dobivenim prilikom prvoga kontakta, impresario je mogao nastaviti skiciranje formalnoga projekta. Susreti i pregovori, po mogućnosti osobni, ostavljali su se za kasnije. Najprije se slalo pismo s prijedlogom za predstavu. Uobičajeno

11 John ROSSELLI, L'impresario d'opera, EDT, Torino, 1985., str. 36.

12 Naziv »opera seria« koristio se u prepiskama i svim dokumentima iz ovog perioda, naglašavajući razliku s »operom buffom«, za koju je bio predviđen drugačiji novčani iznos.

13 Pismo kazališne agencije Ceruso iz Milana kazališnoj direkciji u Splitu, Milano, 9. 1. 1898, HR-MGS: Kazalište 4/I-XVII. 
se predlagala predstava od sezone do sezone pa se tako, primjerice, u svibnju pregovaralo o jesenskoj sezoni. Neki su, pak, predlagali operu na mjesečnoj osnovi (ili čak i u kraćem vremenskom rasponu) ili zbog osobnih kašnjenja u organizaciji ili u nadi da će drugi natjecatelj u danoj sezoni imati poteškoća i stoga biti zamijenjen. ${ }^{14}$

Što su impresariji točno isticali u ovim pismima? Uglavnom osobni izbor umjetnika i opernih djela. Kazališna bi se direkcija potom suglasila s izabranim operama. Međutim, neka su istočnojadranska kazališta morala dobiti i suglasnost sazvanih dioničara. Budući da su ti dioničari sudjelovali u plaćanju izvedbe, nerijetko su zahtijevali sudjelovanje u donošenju odluka, a ako bi sezona bila nezadovoljavajuća, tražili bi i povrat uloženoga novca. Kada bi dioničari bili brojni, kao primjerice u Zadru, njih 48, donošenje bi odluke postajao vrlo kompliciran i dug proces jer se velik broj ljudi međusobno morao usuglasiti. ${ }^{15}$

Neki bi impresario odmah pripremio brošuru namijenjenu kazališnim direkcijama kako ne bi morao pisati i slati desetine istih pisama. Postojale su već manje ili više strukturirane brošure: na prvoj stranici kratak zahtjev o informacijama, na drugoj stranici lista opera ili cjelokupnoga umjetničkog osoblja (za one koji su imali već kompletirano umjetničko osoblje), članova orkestra i zbora te karakteristike glazbe, garderobe, scenografije i opreme. Na trećoj je stranici direkcija mogla navesti u kojim se danima u svakom mjesecu moglo raspolagati kazalištem, potom tu stranicu iskinuti i poslati je natrag impresariju. ${ }^{16}$

Razvojem fotografije, družine poput slavne Compagnia Lillipuziana, pod vodstvom Ernesta Guerre, slale su i svoje fotografije kao reklamni materijal. ${ }^{17}$ Compagnia Lillipuziana sastojala se od mladićâ koje je Guerra okupio, neke čak i spasio teških životnih prilika te ih potom glazbeno educirao. ${ }^{18} \mathrm{Na}$ odjelu su za kazalište u državnim arhivima

14 Usp., npr., pismo impresarija Vecchija upućeno kazališnoj direkciji u Zadru, poslano iz Milana 27. 3. 1885 za predstojeću proljetnu sezonu, HR-DAZD-252, omotnica 5.

15 Tako je Innocente Monass pisao kazališnoj direkciji Zadra: »Poštovana Direkcijo! Uime svoje supruge, vlasnice glavne pozornice br. 10, nedavno sam uložio iznos od 40 kruna za sezonu 1906. Budući da je nakon neuspjeha Rigoletta uslijedio i neuspjeh opere Lucia di Lammermoor, čime se sezona svela isključivo na izvođenje opere Mefistofele, jasno je da će impresariju, koji nije ispunio ugovorene obveze, biti uskraćena bilo kakva subvencija. Molim poštovanu Direkciju da mi isplati navedeni iznos, tim više jer sam upućen da su i drugi vlasnici kazališta s punim pravom odbili isplatiti svoj dio doprinosa." (»Spettabile Direzione! A nome della mia consorte quale proprietaria del palco di I ordine n. 10 ebbi tempo fa a versare il canone di corone 40 per la stagione d'opera 1906. Visto ora che in seguito all'insuccesso del Rigoletto venne anche desistito dalla rappresentazione di Lucia di Lammermoor, e che quindi tutta la stagione d'opera si ridusse alla sola rappresentazione del Mefistofele, e certo che all'impresario sarà stata negata qualsiasi sovvenzione non avendo egli corrisposto ai relativi suoi obblighi contrattuali, prego Essa spettabile Direzione a volermi restituire il suddetto canone, ciò tanto più in quanto mi consta, avere anche altri palchettisti rifiutato con piena ragione e diritto il proprio contributo《), Zadar, 17. 11. 1906, HR-DAZD-252, omotnica 22.

16 Ovaj je uzorak, primjerice, koristila Internacionalna Operna Kompanija u vlasništvu Samuela Lewisa i Wilhema Toma. Pietro Minciotti bio je njezin i direktor i upravnik, HR-DAZD-252, omotnica 5.

17 Više o družini usp. izvještaj Enrica Paganuzzija u: Pierpaolo BRUGNOLI, La musica a Verona, Banca mutua popolare di Verona, Verona, 1976., str. 358. Nije bio prvi put da je družina mladića nastupala u zadarskom kazalištu. Već 1870. gostovala je pjevačka i plesna družina iz Trsta, sastavljena isključivo od dječaka pod vodstvom Giovannija Pascuccija. Primadona je imala 16, a tenor 12 godina.

18 Povodom nastupa ove družine u Teatro Biondo u Palermu pisalo je u Rivista di Roma: »Slavna Compagnia Lillipuziana, pod vodstvom poznatoga maestra Ernesta Guerra, koji je svojim izuzetnim senzibilitetom i strpljenjem uspio podići značajan broj od prosjačkoga štapa spašenih dječaka u prave male 
Šibenika i Zadra sačuvane fotografije na kojima članovi družine nose scensku odjeću s pojedinačnih opera. Ovakve su reklamne djelatnosti predstavljale dodatni trošak, ali su također kazališnim direkcijama pružale neposredan uvid o ponudama. Guerrina družina, koja je raspolagala širokim repertoarom, predložila je, primjerice, Zadru sedam različitih predstava samo za proljetnu sezonu 1906. godine. Uzmimo u obzir da se navedeno ostvarivalo u razdoblju koje je predstavljalo vrhunac financijske krize kazališnoga života. Budući da su družinu činili dječaci u dobi od 10. do 14. godine, plaće su se, dakako, razlikovale od onih predviđenih odraslim pjevačima, čime se moglo uštedjeti na trošku koji je obično najviše opterećivao proračun, odnosno na novčanim naknadama.

Ernesto Guerra uspio je osigurati prve nastupe u Dalmaciji početkom 20. stoljeća zahvaljujući agentu Enricu Galliniju iz Trsta. Kasnije će Guerra, zaobilazeći agente, izravno pregovarati s kazališnim direkcijama. Iako u to vrijeme nerijetko prakticirano, ovakvo bi poslovanje, naravno, izazivalo nezadovoljstvo agenata koji su na ovaj način bili isključeni iz pregovora. U prvoj bi se fazi impresariji, dakle, oslanjali na usluge agencije, kako bi se nakon upoznavanja s predstavnicima kazališne direkcije njima izravno i obraćali. To je značilo uštedu na iznosima namijenjenim agentima.

Zbog očiglednih se zemljopisnih razloga većina putovanja iz Italije prema Istri i Dalmaciji odvijala morem. Kada bi vremenske prilike bile nepovoljne, primjerice, kada bi puhala bura u Trstu, izvođači bi nerijetko kasnili s dolaskom. Ovo se događalo i kada bi se polazilo iz Rijeke.

»Spriječen nastavak putovanja zbog morskih neprilika zakasnit ću« - tako je telegrafski javljao bariton Silvetti kazališnoj direkciji u Šibeniku, ${ }^{19}$ a agent Gallina je brzojavio: »Članovi zbora kreću sutra zbog lošeg vremena [sic] u četvrtak šaljemo pomoćne reflektore $\ll{ }^{20}$ Stoga su probe ili čak same izvedbe mogle biti odgođene.

Kasniti su mogle i pošiljke materijala. Scenografije, koje su obično stizale iz Milana, zajedno s drugom robom, kao što su oprema ili partiture, putovale su izravno vlakom do Trsta, a osobna prtljaga izvođača mogla se slati putem transportne kompanije Gondrand. ${ }^{21}$ Iz Trsta bi zatim stizale u istočnojadranske gradove parobrodom, poput Lloyd Thetisa. U tom su periodu postojale razne pomorske kompanije: osim austrijskoga Lloyda, postojale su i mađarsko-hrvatske i dubrovačke kompanije. Međutim, moguće su bile i transportne komplikacije i pogreške. Znalo se dogoditi da su materijali, očekivani u kazalištu u Šibeniku, umjesto da budu poslani Lloydom, bili poslani brodom Montenegro Generalne Talijanske

izvanredne umjetnike, u periodu između 3. i 10. studenoga u Teatro Biondo di Palermo izvodila je krasne predstave.« (»Dal 3 al 10 novembre hanno avuto luogo al Teatro Biondo di Palermo delle rappresentazioni deliziosissime della celebre Compagnia lillipuziana diretta dal valoroso maestro Ernesto Guerra, che con la sua rara abilità e pazienza ha saputo fare di un buon numero di bambini raccolti sul lastrico, dei veri e piccoli meravigliosi artisti.«), usp. Rivista di Roma, [s.d.] 1904., str. 698.

19 »Impossibilitato proseguire viaggio causa mare pessimo ritarderò«. Telegram baritona Salvettija kazališnoj direkciji u Šibeniku, HR-DAŠI-103, omotnica 9.

20 »Coristi partono domani causa tempo oribile [sic] giovedì partono riflettori accessori«. Telegram agenta Gallinija kazališnoj direkciji u Šibeniku, HR-DAŠI-103, omotnica 9.

${ }^{21}$ Milansko poduzeće Gondrand, nacionalni i internacionalni transportni servis, osnovano 1866. i dalje postoji. Otvorilo je podružnice u 19 talijanskih gradova. 
Navigacije, koji uopće nije ulazio u dalmatinske luke. Štoviše, poslani su kovčezi, prema riječima kazališnoga direktora Mazzolenija, imali »ugodno dugačko putovanje« do Turske i Grčke umjesto da na vrijeme stignu na odredište. ${ }^{22}$

Među pošiljkama nalazili su se i scenski kostimi. Krojačnice, žrtve sve češćih oduzimanja scenskoga materijala zbog nesolventnosti impresarija, rado su se osiguravale naglašavajući tko je bio vlasnik tih materijala.

Tako je, primjerice, običavala postupati kazališna krojačnica Antonio De Caro, koja je 1895. opsluživala kazalište u Splitu. Krojačnica je naročito isticala da je garderoba njihovo vlasništvo, iznajmljivano impresariju. Dakle, ovakav je materijal bilo nemoguće oduzeti:

[...] stoga obavještavam poštovanu Direkciju da je navedena garderoba, kao i ona ubuduće poslana kako bi se koristila za druge opere isključivo moje vlasništvo, iznajmljeno gospodinu Vecchiju, te se na navedenoj robi ne smije primijeniti nikakav čin oduzimanja ili bilo što drugo iz bilo kojega razloga. ${ }^{23}$

Kako bi osigurale povrat garderobe, neke su krojačnice zahtijevale jamčevinu, poput krojačnice Bonaventura \& Hofstätter iz Trsta koja je iznajmljivala kostime kazalištu u Šibeniku. No, direktor kazališta Mazzoleni pisao je impresariju Giuseppeu Ponziju, ispričavajući se da davanje jamčevine u te svrhe nije uobičajeno za kazališta, te se stoga ne bi trebala platiti. Ovaj je slučaj bio tek izuzetak. ${ }^{24}$

22 Pismo Mazzolenija Paolu Roccu, [Šibenik], 6. 2. [1909], HR-DAŠI-103, omotnica 9.

23 »[...] informo perciò codesta on.le Direzione che tanto il sud[detto] vestiario come quello che in seguito si spedirà per rappresentare le altre opere è mia esclusiva proprietà, noleggiato al sig. Vecchi, e sulla detta merce non può quindi esercitarsi alcun atto di sequestro od altro per nessuna ragione.« Pismo Antonija De Caroa upućeno Filomenu Bulatu, direktoru kazališta u Splitu, Milano, 24. 10. 1895, HR-MGS: Kazalište 4/I-XVII.

24 »Pišite gospodinu Bonaventuri da ako se kazališna direkcija u Šibeniku odlučila sačuvati Vam kazalište bez da Vas natjera na plaćanje jamčevine, nešto što je uobičajeno za kazališta, onda bi Vam i krojačnica iz Trsta mogla iznajmiti to nešto malo garderobe, bez potrebe za jamstvom koje svakako ne postoji u običajima kazališta i da Direkcija po principu i bez pravljenja izuzetaka prema krojačnici to ne može odobriti. Impresario poput Vas, ne više nepoznat, već s referentnim imenom u direkciji kazališta u Lussinu, barem ima pravo na ovo malo povjerenja od strane kazališne krojačnice. S njom ja nikada nisam pregovarao znajući da je jako skupa, ali ni od nijedne druge nije ništa slično zahtijevano. Može se prihvatiti samo jedno početno jamstvo, ali ne i navedeno, jer se nikad ne može znati koje bi potrebe mogao kasnije imati gospodin Bonaventura u svezi s povratom garderobe. Kada se radi o direkcijama koje igraju na sigurno, nastaje mnogo toga nepotrebnoga jer gospoda u dobavljanju imaju svakojake zahtjeve.« (»Scriva a quel Signor Bonaventura che se la Direzione del teatro di Šibenik si è fidata di riservarle il teatro senza farLe versare una cauzione cosa che è nelle consuetudini teatrali, anche la sartoria di Trieste può fidarsi di noleggiarLe quei pochi vestiti senza bisogno di garanzie che non esistono nelle consuetudini teatrali e che la Direzione per principio e per non crear precedenti verso la sartoria non può concedere. Un impresario come Lei non più persona nuova ma della quale può dar referenze la direzione del Teatro di Lussino ha il diritto di questo poco di fiducia da parte di una sartoria teatrale. Colla stessa io non ho fatto mai affari sapendola molto cara, ma mai da nessun altra vennero richieste di questo genere. Poteva andare una garanzia richiesta da una prima piazza, ma non dalle piazze successive, inquantochè non si può mai sapere che esigenze può avere più tardi il Signor Bonaventura alla restituzione dei vestiti. Quando si tratta di direzioni sapendo di andare su sicuro creano mille noie e hanno esigenze d'ogni genere 
Što se tiče udjela za pjevače i orkestar, njih bi kazališne direkcije ili impresariji tražili od izdavača i njihovih predstavnika. Poneki bi zahtjevi s jadranske obale stizali od Carla Schmidla, predstavnika kuće Ricordi iz Trsta. ${ }^{25}$ Kazališna direkcija ili impresario slali su popis neophodnih partitura (instrumenti i pjevanje). Ako bi neke bile izostavljene, Schimdl bi ih tražio izravno iz Milana. Drugi su se zahtjevi također mogli uputiti Antoniju Gallu, predstavniku kuće Ricordi »za Veneto i Iliriju«, ili kompaniji Francesco Lucca. Dakle, sklapao se dogovor o najmu različit za svakoga izdavača. ${ }^{26} \mathrm{U}$ nekim se slučajevima partiture ne bi slale parobrodom već normalnom poštom. Poduzeće je preuzimalo troškove u svezi s transportom partitura, kao i depozit kojim bi se osiguralo izvršavanje obveza. ${ }^{27}$ Također, poduzeće bi, između ostaloga, posebno naznačavalo i vlasništvo partitura jer bi u protivnom uslijedila kazna. ${ }^{28}$ Partiture bi, dakle, bile poslane, a njihova bi dostava bila praćena popisom.

Plaćanje vanjskih umjetnika bio je dodatan trošak za impresarija. Nije se sve moglo osigurati interno, točnije, trebalo bi naglasiti da su - kao i u drugim kazalištima na Poluotoku - orkestri bili poluprofesionalni te je stoga potreba za vanjskom pomoći bila stalna. ${ }^{29}$ Nedostajali su i članovi zbora: kolikogod zvučalo čudno, kazalište u Zadru 1884. godine brojalo je samo tri registrirana člana i nijednu članicu. U desetljeću koje je slijedilo, u Splitu nije bilo nijednoga člana zbora, a na raspolaganju je bilo samo 12 glazbenika, ne računajući vođe dionica. ${ }^{30}$ Stoga, impresario koji je nastojao jamčiti jednu sezonu opere serije, morao je osigurati cijeli zborni ansambl i dodati lokalnim glazbenicima najmanje još drugih 18 izvođača. Zadarski je natječaj podrazumijevao otprilike ukupno 40-ak izvođača, a isti je broj javno zahtijevan i u Rijeci 1876. godine, zajedno s 30 članova zbora. Nadolazeći

questi signori fornitori.«) Pismo Mazzolenija impresariju Giuseppeu Ponziju, 8. 4. 1911, HR-DAŠI-103, omotnica 10.

25 Usp., npr., dokumentaciju o vozarini poliuta u Zadru 1914., HR-DAZD-252, omotnica 24; ili zahtjeve Giovannija Mazzolenija poslane iz Šibenika za Trovatore i Traviatu 1909., HR-DAŠI-103, omotnica 9. Carlo Schmidl je 1889. osnovao poduzeće Carlo Schmidl \& Co., koje je kasnije predao kući Ricordi 1902. godine. Za kuću Ricordi otvorio je 1901. podružnicu u Lipsiji, vodeći je do 1906., usp. natuknicu »Carlo Schmidl« u: Dizionario enciclopedico universale della musica e dei musicisti, 7 vol., str. 5.

26 Iako član kuće Ricordi, Antonio Gallo posjedovao je knjižicu za transport jedne operne partiture, drugačiju od one koju je koristila kuća Ricordi i, naravno, drugačiju od one koju je formulirala kuća Lucca. U knjižici je bio određen početak i kraj perioda korištenja dionica, zajedno s transportnim troškovima. Postojala je kazna u slučaju kašnjenja s vraćanjem dionica, iznos koji bi se uvećavao iz tjedna u tjedan. Usp. primjerice knjižicu za vozarinu dogovorenu između poduzeća Francesco Lucca i impresarija Carla Vianella u Zadru 1875., HR-DAZD-252, omotnica 27.

27 Godine 1909. Mazzoleni (koji je te godine bio u službi impresarija) plaćao je 100 lira Schmidlu u ime depozita za iznajmljivanje dionica za operu Trovatore i Traviata, koje su ga sveukupno koštale 400 lira.

28 Prema klauzulama, i oni koji bi djelomice ili cjelovito preslikavali partiture plaćali bi novčanu kaznu. Podrazumijevalo se da bi bilo koje kompozitorske modifikacije u partituri morale biti predane izdavaču. Izdavači su libreta kupovali izravno i nisu se mogli tiskati lokalno.

29 Za usporedbu s opernim orkestrima na Apeninskom poluotoku vidi npr.: Franco PIPERNO - Antonio ROSTAGNO, The Orchestra in Ninteenth-Century Italian Opera Houses, u: Niels Martin JENSEN Franco PIPERNO (ur.), The Opera Orchestra in $18^{\text {th }}$ - and $19^{\text {th }}$ Century Europe, BWV, Berlin, 2008., str. 15-62, zajedno s raznim prilozima koje je Renato MEUCCI osamdesetih i devedesetih godina posvetio temi o uključivanju raznih instrumenata u orkestre.

30 Usp. pismo Antonija Lane kazališnoj upravi u Splitu, Split, 2. 2. 1895., HR-MGS: Kazalište, 3,3 I-XII. 
natječaji u Rijeci su zabilježili porast ovoga broja: 50 glazbenika i 50 članova zbora u 1901., 60 glazbenika i 60 članova zbora u 1909. itd., a porast je bio opravdan obogaćivanjem repertoara. ${ }^{31}$ Isto je važilo i za plesni korpus: dok se u Zadru očekivalo uobičajenih $» 12$ raspoređenih balerina $\ll^{32}$, u Rijeci je početkom 20. stoljeća bilo potrebno njih 30. Događalo se da su najbolje balerine bile na turneji u Americi te su preostajale, prema žalbama impresarija Giorgia Traunera, samo one »ružne, stare i zahtjevne «. ${ }^{33}$ Sama je direkcija kazališta u Zadru priznavala da od šest balerina »četiri znaju plesati. [...] Dvije koje znaju plesati, stare su. Ono što se nazivalo »mizernim plesnim korpusom« doprinosilo je nezadovoljstvu publike. Direkcija je naglašavala da je impresario definitivno morao naći nove (»koje iako ne bi znale plesati, barem bi bile ljepše«, sa žaljenjem je pisano agentu Gallina). ${ }^{34}$ Iz ovoga je vidljivo kako je postojala potreba da se pronađu dodatni članovi baleta. Dakle, novi bi članovi opet izazvali nove troškove.

Pored onih koje bismo danas mogli nazvati »umjetničkim namjerama« naručitelja, detaljna analiza troškova koji bi nastali uslijed prethodno navedenih razloga, može objasniti planiranje i odvijanje sezone. Kako bi se pokrenuo sveobuhvatni diskurs o umjetničkoj djelatnosti istočnojadranskih kazališta - što je također važan aspekt ovoga istraživanja - ne može se izostaviti razumijevanje podređenih ekonomskih mehanizama. Primjerice, shvatiti da nije samo prihod nego i jedan složen lanac čimbenika, među kojima i odnos između prihoda i jamčevine, motivirao impresarija da započne organizaciju operne sezone ili razumjeti da je i konkretna mogućnost likvidnosti impresarija, zajedno s čuvenom solventnosti, bila među glavnim motivima za uspjeh u konkurenciji s drugim kolegama. Sve navedeno proizlazi iz detaljnoga proučavanja dokumenata i nudi jednu dublju perspektivu o mehanizmima kazališne produkcije. ${ }^{35}$

31 Usp. Capitolato d'appalto per l'esercizio del Teatro Comunale nel triennio 1 gennaio 1909 - 31 dicembre 1914, HR-DARI, Općinsko kazalište »G. Verdi«, DS 60.

32 »12 ballerine distinte di fila«. Natječaj Novog Kazališta u Zadru, Zadar, s.d., HR-DAZD-252, omotnica.

33 »Brutte, vecchie e piene di pretese«. Pismo Giorgia Traunera kazališnoj direkciji u Zadru, Milano, 12.7.1906, HR-DAZD-252, omotnica 26.

34 »che se anche non sapranno ballare saranno almeno più presentabili di queste«. Kazališna direkcija u Zadru agentu Enricu Galliniju, [Zadar, 1906], HR-DAZD-252, omotnica 21.

35 Željela bih zahvaliti na pruženoj pomoći ravnateljima i osoblju arhiva u Pazinu, Rijeci, Šibeniku, Zadru i Dubrovniku, ravnateljima gradske knjižnice u Puli i gradskoga muzeja u Splitu. Za prijevod ovoga članka s talijanskoga na hrvatski jezik odgovorna je Noemi SILVESTRI. 


\section{SAŽETAK \\ Bilješke o opernom kazališnom poduzetništvu istočnoga Jadrana u austrougarskom razdoblju}

Analiza kazališnih fondova sačuvanih u državnim arhivima i knjižnicama te muzejima na istarskoj i dalmatinskoj obali omogućuje nam upoznavanje identiteta $i$ aktivnosti opernih impresarija koji su djelovali na tom području u kasnom austrougarskom razdoblju. Riječ je uglavnom bila o talijanskim impresarijima koji su nastojali osigurati pristup brojnim kazalištima, kao i određen broj predstava. Uzimajući u obzir ekonomske rizike kojima su impresariji išli ususret, kao i značajne troškove koje je organiziranje operne sezone iziskivalo, zasigurno bi se isplatio oslonac na dobro utemeljen sustav, poput onoga koji je Pietro Ciscutti 1884. predlagao. Ciscutti je nastojao povezati kazalište Politeama u Puli, koje je i osnovao, s onima u Rijeci i Zadru, pa i s kazalištima u Šibeniku i Dubrovniku. Ova se umreženost ipak nije dogodila, između ostaloga, i zbog Ciscuttijeve smrti nekoliko godina kasnije.

Proučavanje suradnje među impresarijima dopušta započinjanje sveopćega diskursa o najčešćim zahtjevima upućenima kazališnim direkcijama, kao i o umjetničkim prijedlozima te o ponuđenome umjetničkom kadru. Impresariji su, kao i većina umjetnika, dolazili iz Italije parobrodima. Scenska oprema, kostimi i partiture također su bili prenošeni tim putem. Ponekad se kasnilo s polascima, primjerice, kada bi puhala bura, što bi ugrožavalo održavanje proba i/ili same predstave.

Plaćanje vanjskih umjetničkih suradnika predstavljalo je dodatne troškove za impresarije. Na teritoriju su često nedostajali članovi orkestra, zbora i baleta te su se oni morali angažirati izvana kako bi se ispoštovao broj, prema natječajima kazališta, nužnoga osoblja. Tijekom godina su potrebe za umjetnicima rasle.

Poznavanje ekonomskih mehanizama koji reguliraju proizvodni sustav, zatim analiza prihoda i rashoda te razumijevanje odnosa među impresarijima, kazališnim direkcijama i izdavačima, omogućuju nam da ostvarimo dublju perspektivu koju nudi pronađena dokumentacija.

\section{SUMMARY}

\section{Notes on operatic theatrical entrepreneurship of the eastern Adriatic in the Austro-Hungarian period}

The analysis of theatre fonds preserved in state archives, libraries and museums on the Istrian and Dalmatian coasts enables us to get familiar with the identity and activities of opera impresarios active in this area in the late Austro-Hungarian period. These were mostly Italian impresarios that sought to provide access to numerous theatres but also a 
certain number of performances. Taking into consideration the economic risks faced by the impresarios, as well as the significant costs incurred by organizing an opera season, being supported by a well-founded system, such as the one suggested by Pietro Ciscutti in 1884, would certainly have paid off. Namely, Ciscutti sought to connect the Politeama Theatre in Pula, which he founded, with those in Rijeka and Zadar, even with the theatres in Šibenik and Dubrovnik. This networking did not happen, among other things, because of Ciscutti's death a few years later.

The study of the co-operation among the impresarios allows the commencement of a universal discourse on the most common requirements addressed to theatre directorates, as well as on the offered artistic proposals and artistic staff. Impresarios, along with most of the artists, came from Italy by steamships. Stage equipment, costumes and musical scores were also transported in the same way. Sometimes departures were delayed, for example due to strong gusts of bora wind, which would hinder rehearsals and/or shows.

Paying for external artists was an additional cost to impresarios. Members of the orchestra, choir and ballet often could not be found locally and had to be hired from the outside in order to comply with the number of the necessary staff required by theatre competitions. Over the years, the need for artists grew.

The knowledge of the economic mechanisms regulating the production system, the analysis of revenue and expenditure and the understanding of the relationships between impresarios, theatre directorates and publishers, allow us to achieve the deeper perspective provided by the documentation found.

\section{RIASSUNTO}

\section{Appunti sull'imprenditoria relativa al teatro lirico dell'Est adriatico nel periodo dell'Impero austro-ungarico}

L'analisi dei fondi teatrali conservati negli archivi e biblioteche nazionali nonché nei musei sulla costa dell'Istria e della Dalmazia ci aiuta a conoscere l'identità e le attività degli impresari d'opera lirica che operavano nel territorio nel periodo del tardo impero austro-ungarico. Si tratta perlopiù di impresari italiani che cercavano di rendere possibile l'accesso ai numerosi teatri e un determinato numero di rappresentazioni. Prendendo in considerazione i rischi economici a cui gli impresari andavano incontro, nonché le notevoli spese che dovevano sostenere per organizzare una stagione d'opera, di sicuro sarebbe convenuto il sostegno di un sistema ben fondato, come quello proposto da Pietro Ciscutti nel 1884. Ciscutti ha cercato di collegare il teatro Politeama di Pola, che lui stesso fondò, con quelli di Fiume e Zara, poi con i teatri di Sebenico e Ragusa. Non si è giunto poi a questo collegamento, tra l'altro anche per via della morte di Ciscutti avvenuta alcuni anni dopo.

Lo studio della collaborazione tra gli impresari permette l'inizio di un discorso generale sulle richieste più frequenti indirizzate alle direzioni teatrali nonché sulle proposte ar- 
tistiche e sullo staff artistico offerto. Gli impresari, come tra l'altro la maggior parte degli artisti, venivano dall'Italia con le navi a vapore. L'attrezzatura da palcoscenico, costumi e spartiti, arrivavano nello stesso modo. Qualche volta le partenze erano rinviate, per esempio, quando soffiava la bora, e questo poneva in pericolo le prove e/oppure le rappresentazioni.

Il pagamento dei collaboratori artistici esterni rappresentava spese aggiuntive agli impresari. Nel territorio spesso mancavano membri d'orchestra, del coro e ballerini e per questo motivo era necessario avvalersi di collaboratori esterni per rispettare il numero dell'organico necessario, in base ai concorsi del teatro. Negli anni successivi aumentava il bisogno degli artisti.

La conoscenza dei meccanismi economici che regolano il sistema di produzione, poi, l'analisi dei ricavi e dei costi e la conoscenza dei rapporti tra impresari, direzioni teatrali ed editori, ci rendono possibile di creare una prospettiva più profonda offerta dalla documentazione ricavata. 